\title{
Cellular Automata Markov Method, an Approach for Rice Self-Sufficiency Projection
}

\author{
Dewayany Sutrisno ${ }^{1}$, Wiwin Ambarwulan ${ }^{1}$, Irmadi Nahib ${ }^{1 *}$, Turmudi', \\ Jaka Suryanta ${ }^{1}$, Rizka Windiastuti ${ }^{1}$, Priyadi Kardono ${ }^{1}$ \\ 1 Centre for Research, Promotion and Cooperation, Geospatial Information Agency Jl Raya Jakarta Bogor Km 46, \\ Cibinong Bogor City, 16911, Indonesia \\ * Corresponding author's e-mail: irmnahib@gmail.com
}

\begin{abstract}
This article discusses the ability of the Cellular Automata (CA) Markov method to project rice sufficiency by considering the conversion of massive rice fields, such as the ones in Indonesia. The conversion of rice fields into land use for non-farming due to the rapidly growing population, industry and economic needs is increasingly affecting the rice self-sufficiency. With the development of remote sensing techniques, such as CA Markov, which has been used for years in spatial change projection, there is a need to assess the rice field conversion and its impact on the rice field self-sufficiency. The process is not solely based on CA Markov but also includes an object-based classification method utilising multi-temporal spot image data to derive land use maps, CA Markov for rice field conversion projection and rice self-sufficiency assessment, which was developed by assessing the availability of rice, consumption and production. Using the Indramayu district as the study area, the results indicate that within the next 20 years, the rice field area will decrease, and the impact on rice self-sufficiency will be 5.34 for Business as usual (BAU) and 0.47 when considering population growth. The previous research validated the results and indicated the efficiency of this method for rice self-sufficiency projection. Moreover, a management assessment was also conducted and indicated that in order to maintain rice self-sufficiency, innovation in the planting and seed systems as well as in farmers' welfare management, such as incentives and subsidies, local food diversification systems and innovative food technique development to support food diversification, should be considered.
\end{abstract}

Keywords: rice field, conversion, food security, intensification, food, Indramayu Indonesia

\section{INTRODUCTION}

Agricultural land has an important function in the sustainability of food production across generations as well as in cultural values. However, the continuing existence of agricultural land is faced with critical pressures due to massive infrastructure, suburban and business area development. The economic and population growth may become the triggers of this land conversion (Azadi et al., 2010). Neither developed nor developing countries can avoid this land conversion phenomenon, including Indonesia. In Indonesia, one of the critical issues is the conversion of rice fields, as it has a permanent impact on and represents a genuine risk to national food security (Pasandaran, 2006;
Irawan, 2005). The rice fields that have been converted to other uses are unlikely to change back (Pasandaran, 2006). Similarly, the efforts to build new rice fields do not compensate for the loss of production, as it takes a long time to develop high productivity levels (Pasandaran, 2006).

In recent decades, the rate of rice field conversion has been increasing. Mulyani et al. (2016) performed a remote sensing analysis of the nine provinces of Indonesia from 2013 to 2015, estimating a rice field conversion of 96,512 ha/ year, with the conversion rates varying between high ( $>4 \% /$ year), moderate ( $2-4 \% /$ year) and low $(<2 \% /$ year $)$. Presuming moderate conversion rates, only around 200,000 ha of rice fields will remain by 2045 , compared to 1.7 million ha in 
2014 (Mulyani et al., 2016). At least 50,000 to 100,000 hectares of rice fields are lost each year, either due to land conversion or to the stagnant regeneration of farmers, which results fields no longer cultivated by farmers (Pikiran Rakyat, 2016).

The extent of rice field conversion nationally has become a science-based spatial issue rather than strictly a statistical issue. Remote sensing has been generally utilized to assess land cover and the land use changes directly related to rice field conversion. For example, the United States Department of Agriculture has developed land cover maps derived from yearly satellite imagery in order to emphasize the situations that would need special attention, propose solutions to key problems as well as suggest suitable practices and universal guidelines for the cropland data layer (Lark et al., 2017). Indeed, Wang et al. (2016) utilized land cover and land use changes developed from multi-temporal remote sensing data in a spatial regression model to provide more accurate policy recommendations. Many methods have been established to assess the changes in land cover and land use, from simple change detection to the CA Markov model, which could be used to predict cropland conversions. For example, Kamusako et al. (2009) projected the changes of land use cover using spatial data up to year 2030 based on a CA Markov model, which incorporates Markovian transition prospects calculated from satellitederived land cover/use maps and a spatial filter for cellular automata. Further, Guan et al. (2011) utilized a combined CA Markov model to analyse the spatial and temporal distribution changes in land use based on natural and socioeconomic elements in Saga, Japan. Zare et al. (2017) used a revised universal loss equation and CA Markov model to study the potential impact of land use transformations on soil erosion in Iran.

Considering that rice is a main staple food in Indonesia, the assessment of rice field conversion should project the self-sufficiency of rice production to support the food security programs. The effectiveness of remote sensing analysis in food security projection and determination of the best management parameters for responding the projection are the main research questions in this article. Therefore, this article intends to assess the ability of the CA Markov method to project rice field conversion and its related impact on rice self-sufficiency. A management issues assessment was also implemented for assessing the possible scenarios to achieve self-sufficiency. The
Indramayu district - West Java province where the largest areas of rice fields are found, also characterized by the highest conversion rate of about $1.80 \%$ per year (Butar Butar, 2012), was selected as the study area.

\section{DATA AND METHODS}

\section{Area study}

This research was performed in the Indramayu District, West Java Province, Indonesia. Geographically, the district is located at $107^{\circ} 52^{\prime}-108^{\circ} 36^{\prime} \mathrm{E}$ and $06^{\circ} 15^{\prime}-06^{\circ} 40^{\prime} \mathrm{S}$ (Figure 1). Administratively, the region consists of 31 subdistricts and 309 villages. The district covers an area of approximately 209,942 ha, with a long coastline of approximately $147 \mathrm{~km}$ that stretches along the north coast of Java Island. The district lies at the north coast of Java Island, its physiographic is lowland with a slope of less than $8 \%$, covering $56 \%$ of the area. In the Indramayu District, one of the rice production centers in Indonesia the dominant land use involves paddy fields which cover $>60 \%$ of the district. This is in accordance with the research conducted by Ambarwulan et al. (2017) about the suitability of paddy fields in the Indramayu District. It was stated that more than $70 \%$ of the paddy fields in this district belong to the S2 category (suitable) and the rest are in the $\mathrm{S} 3$ category (marginally suitable).

\section{Method}

An object-based supervised classification method was implemented to derive land use maps. The land use maps were developed from SPOT 6 images, obtained in 1994, 2008 and 2015. This method was selected, because it is currently experiencing rapid advances in spatial resolution that correlated with the optimal segmentation scale and study area (Ma et al., 2017). The land use objects were classified into three classes: irrigated rice fields, rain-fed rice fields and not rice fields. Then, the impact of the rice field transformation on food security was assessed using the methods described in the following chapter.

\section{Projection of rice field availability using the Markov method}

The CA Markov method was used for assessing the projection of land use change. This 


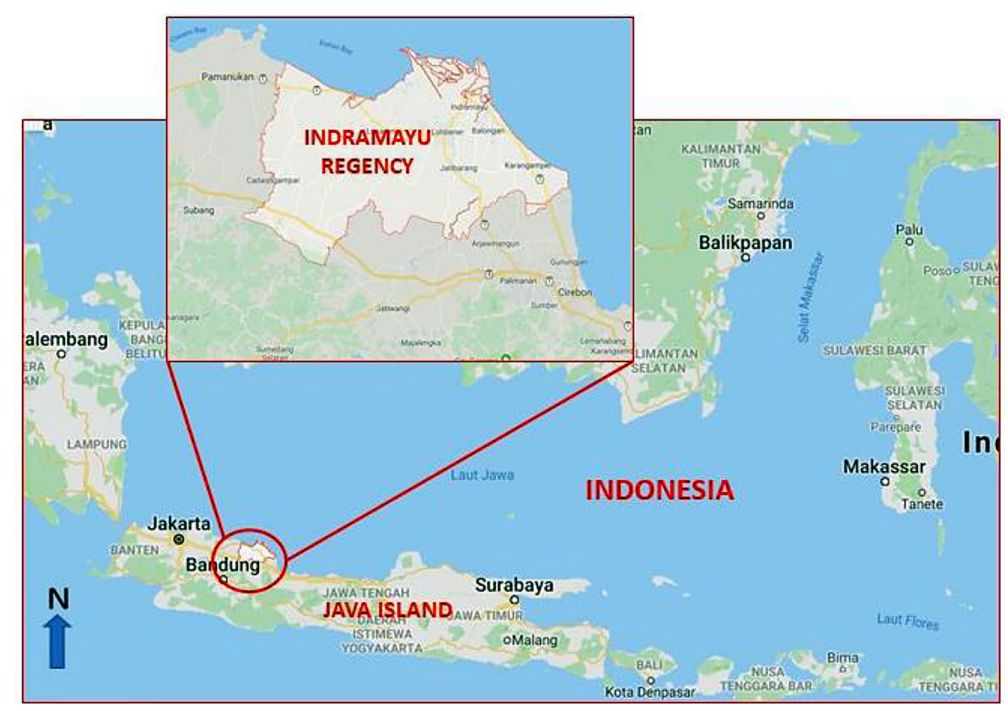

Figure 1. Study area, Indramayu District

method was selected due to its ability to look for future probabilities by analysing current probabilities, with the goal to project the future (Render, 2006). The CA Markov model is a mixture of the Markov chain procedure and the concept of a cellular automata filter (Mondal et al., 2016; Hou et al., 2005), and it can be expressed as follows:

$$
\mathrm{S}=(\mathrm{t}, \mathrm{t}+1)=\mathrm{f}(\mathrm{S}(\mathrm{t}), \mathrm{N})
$$

where: $S$ is the cellular states,

$N$ is the cellular field,

$t$ and $t+1$ are different times and

$f$ is the conversion rule of cellular states in local space.

The Markov model is a concept based on the procedure of developing Markov arbitrary system for the forecast and an ideal method of control theory (Mondal et al., 2016). Considering the conditional likelihood formula, the forecast of land use changes can be calculated by means of equation (2) (Mondal et al., 2016; Xiyong et al., 2005; Yang et al., 2007, Jiang et al., 2009) as follows:

$$
S(t+1)=P_{i j} x S(t)
$$

where: $S(t)$ and $S(t+1)$ are status of the system at time $\mathrm{t}$ or $\mathrm{t}+1$; $\mathrm{Pij}$ is the conversion possibility matrix in a situation calculated as the following equation

$$
P=\left(p_{i j}\right)=\left|\begin{array}{ccc}
P_{11} & P_{12} & P_{1 n} \\
\ldots & \ldots & \ldots \\
P_{n 1} & P_{n 2} & P_{n n}
\end{array}\right|, \sum_{j=i}^{n} p_{i j}=1
$$

where: $P$ is the Markov conversion matrix, $n$ is the number of land use/cover types in the target area,

$i, j$ is the land use/cover type of the first and second time period, and

Pij is the possibility of conversion from land use/cover type $\mathrm{i}$ to type $\mathrm{j}$.

In the conversion matrix, every rate is a nonnegative value, with every line factor from 0 to 1 . The approximate of Markov chain is based on the relative frequency of conversions observed over the total time period. The result of the approximation can be used for forecast (Mondal et al., 2016).

\section{Assessing rice production and consumption}

The amount of agricultural land will continue to diminish even though the demand for food is expected to increase by $50-60 \%$ (Widayati, 2015). The question that arises is how people can be fed, considering that everyone has the right to food and that this right must be guaranteed by the government (Widayati, 2015). Therefore, the equation of Rahman (2001) was employed to assess the need for rice, as determined by the area of rice field conversion, production and population, and can be illustrated in the following formula:

$$
R_{n}=\frac{A_{t_{0}}}{A_{t_{1}} * P^{*} R_{p}}
$$

where: $R n$ is the availability of rice,

Ato is prior area of rice field,

At1 is area of rice field conversion,

$P$ is the population and

$R p$ is rice consumption/person 
In this case, the availability of rice $=$ the need for rice $=$ minimal food security.

Meanwhile, the rice self-sufficiency can be understood as the ratio of net rice production to the actual rice consumption (Abrar, 2008; Adelina et al., 2013; Baliwati, 2014, and Asmarani, 2016), as follows:

$$
R S=\frac{P R}{C R}
$$

where: $R S$ is rice self-sufficiency,

$P R$ is net rice production and

$C R$ is rice consumption

The category of rice self-sufficiency refers to the food and nutrition awareness system (SKPG) presented in Table 1 (Ministry ofAgriculture, 2014)

The rice self-sufficiency ratio then becomes an input for the management scenarios, which will be assessed based on a literature review.

Table 1. The ratio of net production to actual consumption (Ministry of Agriculture, 2014)

\begin{tabular}{|c|c|c|}
\hline \multicolumn{1}{|c|}{ Indicators } & Value of RS & Category \\
\hline $\begin{array}{l}\text { Ratio of net rice } \\
\text { production and rice } \\
\text { consumption }\end{array}$ & $>1.14$ & surplus \\
\cline { 2 - 3 } & $0.9<\mathrm{RS}<1.14$ & self-sufficiency \\
\cline { 2 - 3 } & $<0.9$ & deficit \\
\hline
\end{tabular}

\section{RESULTS AND DISCUSSIONS}

\section{Rice field conversion and self-sufficiency}

The land use classification of irrigated rice fields, rain-fed rice fields and not rice fields in 1994, 2008 and 2015 indicated that rice field conversion occurred in the Indramayu district (Figure 2, Table 2).

The area of irrigated rice fields has continued to decline over the last 21 years, with about 3,140 ha having been converted into other usages. Meanwhile, the rain-fed rice fields have not significantly diminished (just about 143 ha have been lost). The case for rice field conversion was correspondingly noticed by Asmarani (2016), who presented that the production of rice in the Indramayu District has decreased at an average of $4.16 \%$ per year from 2011 to 2015 . She stated that rice field conversion was one of the reasons for the decline in rice production

Most rice fields in the Indramayu District are irrigated, and they are usually located in lowland areas. Such areas are generally the best sites for industrial, settlement and other infrastructure development. In addition, their accessibility and strategic geographical location, including the central business regions such as Bekasi, Bogor and Bandung, also lead to rice field conversion. The land rent value for agricultural land is usually lower when compared to the industrial and residential land (Kamilah, 2013; Barlowe, 1978). Moreover, Kamilah (2016) stated that the land use with higher land rent will predominate, suppress and replace the land use with a smaller land rent value. The value of land rent for rice fields is $1,805 \mathrm{IDR} / \mathrm{m}^{2} /$ year before conversion. After conversion, the value increases to $6,547 \mathrm{IDR} / \mathrm{m}^{2} /$ year (Kamilah, 2016). The land rent values are higher for settlement and industrial land, 25,075 IDR/ $\mathrm{m}^{2} /$ year and 594,321 IDR $/ \mathrm{m}^{2} /$ year, respectively (Kamilah, 2016). Thus, it is unsurprising that most land conversion in Indramayu has occurred as a result of the developments in settlement and industrial lands.

Rice field conversion is responsible for the lack of rice (Rn), which amounted to $232.48 \mathrm{~kg}$ at the end of 2015. The calculation was based on the total population of the Indramayu District in 2015, approximately 1,718 million people (BPS, 2015), considering the average annual rice consumption of about $102.38 \mathrm{~kg} /$ person/year (Ministry of Agriculture, 2015; BKP, 2010). However, rice self-sufficiency in the Indramayu District did not appear to have been disturbed by the conversion of rice fields. This was indicated by the analysis of rice self-sufficiency ratio (about 5.34 in 2015). The assumption for this calculation was that the rice production in the Indramayu District amounted to $70 \mathrm{kw} / \mathrm{ha}$ (BPS, 2015). The abovemetnioned ratio of rice self-sufficiency was close to that found by Asmarani (2016), which reached about 4.75, and that found by Saputra (2015), which approximated 4.95 . The slight differences in these values were likely related to the source of data, which included remote sensing or spatial data assessment in the present study and statistical data in the previous ones.

Considering that the ratio exceeds 1.1.4, the Indramayu District was experiencing a surplus and could maintain its role as one of the national rice barns. Similarly, Asmarani (2016) found that the Indramayu District had a rice surplus from 2011 to 2015, but the rice self-sufficiency declined by as much as $-1.76 \%$ for 2011 to 2015 . According to Luan et al. (2013), the decreases and 
a)

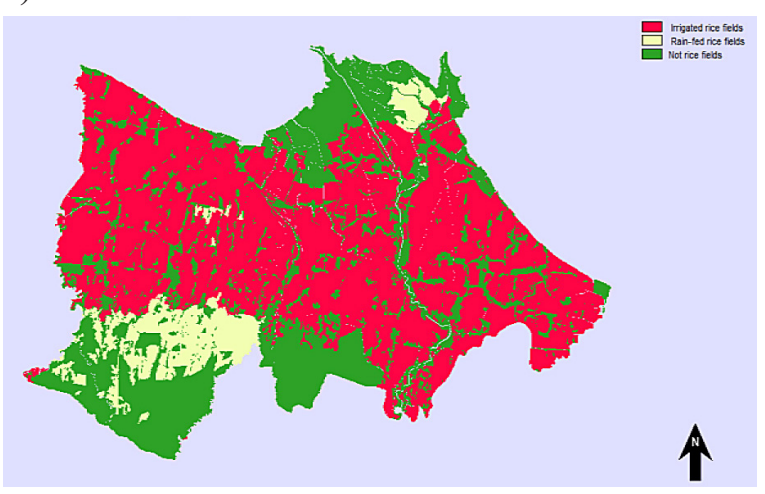

b)

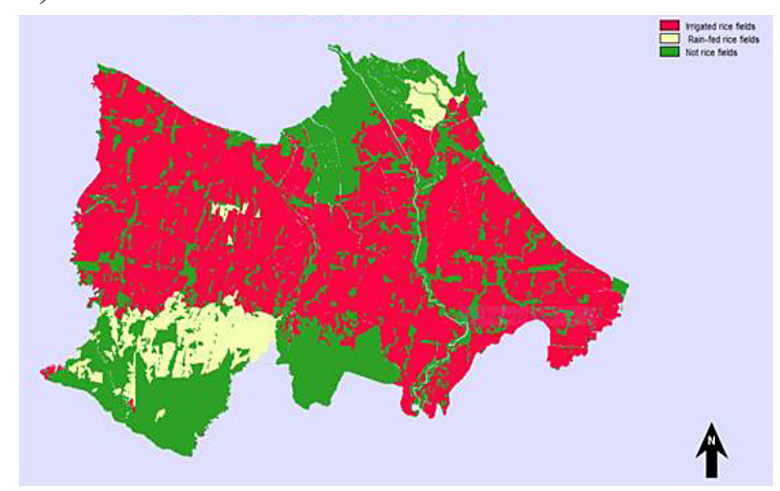

c)

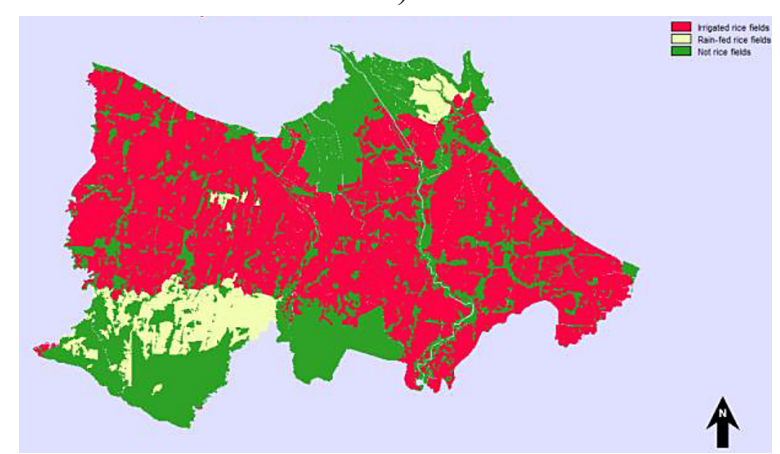

Figure 2. Land use conversion from 1994 to 2015: a) Status of rice fields in 1994, b) Status of rice fields in 2008, c) Status of rice fields in 2015

Table 2. The rice fields conversion data from 1994-2015 (in hectares)

\begin{tabular}{|c|c|c|c|c|}
\hline Classes & 1994 & 2008 & 2015 & Change 1994-2015 \\
\hline Irrigated rice fields & $122,054.040$ & $119,448.440$ & $118,913.840$ & $-3,140.200$ \\
\hline Rain-fed rice fields & $15,495.520$ & $15,313.080$ & $15,352.200$ & -143.320 \\
\hline Not rice fields & $68,708.520$ & $71,496.560$ & $71,992.040$ & $3,283.520$ \\
\hline \multicolumn{4}{|c|}{ Total rice fields conversion } & $-3,283.520$ \\
\hline
\end{tabular}

increases in the self-reliance ratio of foods could be caused by an increase in the gap between the rate of growth of production and the rate of food consumption. With a rate of population growth of approximately $0.5 \%$ per year in 2015 , a problem in the growth of production related to rice field availability could be projected.

\section{Projection of rice fields and rice sufficiency}

Currently, the rice field availability is one of the crucial parameters for maintaining food selfsufficiency. Using the CA Markov analysis, the projection of rice field availability until 2035 can be seen in Figure 3 and Table 3.

The result of spatial projection under the business as usual (BAU) condition indicates a decrease in the area of irrigated rice field of
$3,139.32$ ha and in rain-fed rice fields of 270 ha within the next 20 years. This projection ignores the pattern of suburban, business, or infrastructure development, population growth and other socio-economic factors and is simply based on CA Markov projection only. However, when the population growth is considered in assessing the rice consumption, there is the decrease in the rice self-sufficiency value to 0.47 for the year 2035, in contrast to the slight decline in the rice field area projection. The population rate is assumed to be $0.5 \%$ per year and the production per ha is assumed to be $70 \mathrm{kw} / \mathrm{ha}$, with no further technological input. Hence, within 20 years, the rice self-sufficiency in the Indramayu District will no longer exist (rice self-sufficiency value $<0.9$ ). Despite the need to further assess the rice field projection by employing critical rice field 
a)

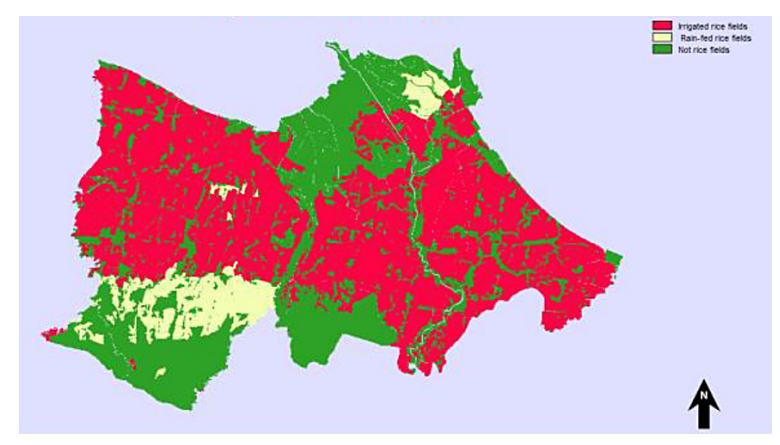

b)

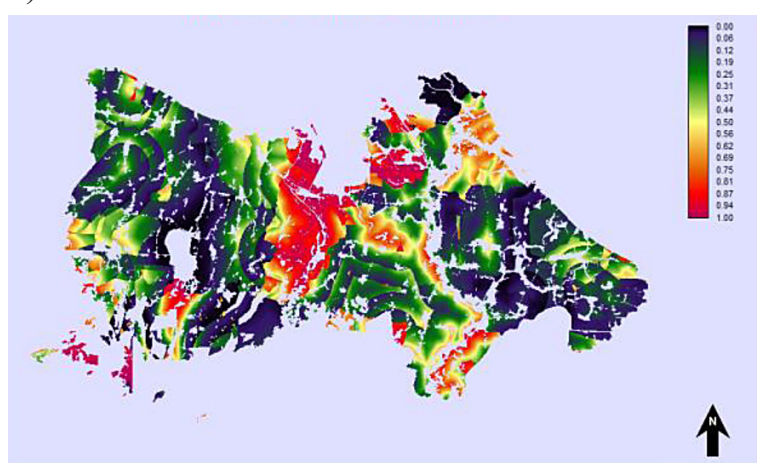

Figure 3. Projection of rice field until 2035: a) projected of rice field until 2035, b) projected potential for transition

Table 3. The projection of rice fields until 2035

\begin{tabular}{|c|l|c|}
\hline No & \multicolumn{1}{|c|}{ Classes } & Area(ha) \\
\hline 1 & Irrigated rice fields & $122,054.040$ \\
\hline 2 & Rain-fed rice fields & $15,495.520$ \\
\hline 3 & Not rice fields & $68,708.520$ \\
\hline
\end{tabular}

conversion parameters, a warning regarding the impact of rice field conversion on the local and national food security programmes should be given. A policy protecting rice fields should be implemented immediately. The regional government of the Indramayu District has enacted Regulation 16/2013 on the Protection of Sustainable Crop Land (Kementerian Dalam Negeri, 2013), but its effectiveness in stopping land conversion remains unknown since the settlement development is on-going. Importantly, the assessment indicates that the CA Markov method can be employed to project the rice field conversion and its impact on the rice self-sufficiency.

\section{Rice production management issues}

The solutions to overcoming the failure of rice self-sufficiency were also assessed here. The main idea is that the rice self-sufficiency can be maintained through increased production and decreased consumption of rice. Increased rice production can be achieved through the implementation of a rice production intensification programme to improve productivity. Nahayo et al. (2017) supported the idea that the crop intensification programme (CIP) is an answer to land fragmentation, low use of agricultural inputs and low access to extension services.

Initially, agriculture intensification was pursued by the Panca Usaha Tani (five-farming) programme, covering the following activities: (1) good soil processing, (2) regular irrigation, (3) selection of best quality seeds, (4) fertilisation and the (5) management of pests and plant diseases (Zaini, 2009). The Panca Usaha Tani (fivefarming) programme then changed into the Sapta Usaha Tani (seven-farming) programme with the addition of (6) post-harvest and (7) marketing strategies (Rohi, 2008). These programmes were successful in bringing the crop self-sufficiency to the nation in the last few years. Currently, this programme needs to be improved by adding technology innovation. For this reason, the regional government of the Indramayu District has implemented Regent Instruction Number 3/2014 regarding the acceleration of technology innovation for rice using a double-row planting system (jajar legowo system) (Indramayu District, 2014). A double-row planting system is a rice transplanting system that involves making empty rows between 2-4 rows of rice plants, with plant spacing within rows that is half that of normal plant spacing (Erythrina and Zaini, 2014; Badan Litbang Pertanian, 2014). Double-row planting aims at increasing the number of plants per unit area, expand the influence of border effects and make plant maintenance easier (Erythrina and Zaini, 2014). This system is believed to have the second largest impact on increasing the rice production after fertilisation (Erythrina and Zaini, 2013). Similarly, an innovation called PATBO (Controlled Rice Aerob with Organic Material Use) has also been developed. PATBO SUPER is a package of technology-specific rice cultivation on rain-fed land using a water management base and organic materials to ensure high productivity while potentially increasing the cultivation index (IP) (jpnn, 2017). The yield per rice tiles showed that the application of PATBO SUPER could increase the rice productivity by $33 \%$ (jpnn, 2017). This innovation 
can also be applied within the rice rain-fed area in the Indramayu District to improve production.

Agricultural intensification can be obtained not only by strengthening the collective capacity of farmers in managing the rice field production, but also by providing incentives to the farmers, both individually and collectively. The regional Indramayu government has launched an agricultural insurance programme to protect farmers. In the United States, the main direct mechanism through which agriculture is subsidised is the government-administered crop insurance and denotes more than $\$ 100$ billion in liabilities every year, as well-designed and executed policies are crucial for aligning sustainability incentives and enabling agricultural productivity growth in the future (Woodard, 2016). Incentives and subsidies for promoting sustainable crop intensification (SCI) have been recognised as a way to escalate the crop productivity and improve livelihoods in rural areas; the concept of SCI can also be applied in managing national rice field production. Incentives and subsidies promoting integrated pest control, small-scale mechanisation and mineral fertiliser usage on conventional cereal grains could result in a tremendous growth in productivity and would bring $94 \%$ of the population out of poverty (Yami and Van Asten, 2017).

Farmer groups should be strengthened at various levels to obtain the optimal sustainable rice product. This could also have an essential impact on protecting rights of the farmers in regional trade. Direct subsidies to farmers, such as beneficial prices for farmers, seeds and fertilisers, as well as incentives for farmers, such as tax breaks for the farmers that maintain their rice fields and scholarships for the young generation of farmers, would be beneficial. Hence, cooperative institutions are still needed at the village level. The governmental intervention in the future development of agricultural institutions must be strengthened (Suradisastra, 2006). Therefore, the development of agricultural institutions and counselling programmes needs to be continued and advanced.

In addition, food self-sufficiency can also be pursued through the consumption patterns based on ensuring balanced nutrition and food diversification. Indeed, food diversification is a policy that should be urgently implemented to reduce the high demand on rice as a staple food. Local crops could serve as alternatives within villages or regions. Suyastiri (2008) assessed the diversification of consumption patterns by combining rice with other crops, i.e. rice-corn, rice-cassava, ricecorn-cassava, showing that it is possible to decrease the dependency on rice. This programme is accessible for low-income households within village areas. Furthermore, the development of technology has given rise to rice analogues, that is, artificial rice made from other crops including corn, cassava, sweet potato, sorghum, sago and daluga. The rice analogues which have characteristics similar to rice can be produced using an extrusion technique (Novisari et al., 2013). However, the targets and marketing of such analogues require further assessment. Food diversification requires identifying and adopting nutritional patterns and crop variety that lower environmental impacts and improve health. The production systems based on the use of heterogeneous cultivars provide a variety of diets and hence contribute to improved human well-being and fitness (Dwivedi et al., 2017).

\section{CONCLUSIONS}

The conversion of agricultural land into nonfarm development has a significant impact on food security. The study conducted in the Indramayu District illustrated that the status of rice production will change within this district from a surplus to a deficit due to the rice field conversion along with the population growth under the BAU state. The rice field conversion projection was developed based on a remote sensing assessment involving an object-based classification method and the CA Markov method, which has proven reliable in rice field conversion as well as in rice self-sufficiency projection. However, the management issues were not assessed in this study, although certain factors related to maintaining selfsufficiency were analysed, such as the consistent government policy. The factors that should be addressed to meet the needs of management policy include technological innovation in planting and seed system, farmers' welfare management (e.g. incentives and subsidised, local food diversification systems) and food innovation technique development to support food diversification.

\section{Acknowledgements}

The authors would like to sincerely thank all those who helped, including Centre for Research, Promotion and Cooperation, Geospatial Information Agency (BIG) for the data and financial support. 


\section{REFERENCES}

1. Abrar H, Khomsan A, Heriyatno Y. 2018. Analysis of Food Security Cattle Based System to Consolidate The Food Security in West Lampung District (in Indonesian). Jurnal Gizi dan Pangan. 3(3), 205-211

2. Adelina SP, Lubis, S. N., \& Ayu, S. F. 2012. Analysis of Availability and food Availability in Medan. Journal of Agriculture and Agribusiness Socioeconomics, 2(1), 1-13.

3. Ambarwulan W, Widiatmaka, Suparwati, T, Firmansyah I, Niendyawati. 2017. Land Suitability and Dynamic System Model for Land Use Planning of Paddy Field in Indramayu Regency, Indonesia. FIG Working Week 2017 Surveying the world of tomorrow - From digitalisation to augmented reality Helsinki, Finland, May 29-June 2, 2017

4. Asmarani, DP. 2016. Analysis of Rice self-sufficiency in Indramayu District from 2011-2015 (in Indonesian). Thesis. Bogor Agricultural University. Bogor.

5. Azadi, H., Ho, P., \& Hasfiati, L. 2010. Agricultural land conversion drivers: A comparison between less developed, developing and developed countries. Land Degradation \& Development, 22(6), 596-604

6. BPS (Badan Pusat Statistik/ Central Agency on Statistic). 2015. Statistics in Numbes: Indramayu Regency (in Indonesian). Indramayu.

7. BKP (Badan Ketahanan Pangan). The Strategic Planning of The Food Security Council, year 2010-2014 (in Indonesian)

8. Baliwati YF. Analysis of Nuts Security in 26 District/City- West Java 2012 (in Indonesian). Delivered on National Symposium on The Role of Soybeans and its Processed Product to The Human Health, Jakarta 18 Juni 2014.

9. Barlowe R.. 1978. Land Resource Economic. Michigan State University. Printice Hall. Engglewood Cliffs. New Jersey (USA).

10. Butar Butar, E. 2012. Analysis of Irrigated Rice Fields Conversion in West Java (in Indonesian). Thesis. Bogor Agricultural University, Bogor.

11. Dwivedi, S.L., van Bueren, E.T.L., Ceccarelli, S., Grando, S., Upadhyaya, H.D., \& Ortiz, R. 2017. Diversifying food systems in the pursuit of sustainable food production and healthy diets. Trends in plant science; 22(10), 842-856.

12. Erythrina, E and Zaini, Z. 2014. Rice Cultivation with Double Row Planting System: Review of Methodology to Obtain Optimal Yield (in Indonesian). Journal Litbang Pertanian; 33(2), 79-86

13. Guan, D., Li, H., Inohae, T., Su, W., Nagaie, T., \& Hokao, K. 2011. Modeling urban land use change by the integration of cellular automa- ton and Markov model. Ecological Modelling; 222(20-22), 3761-3772. doi.org/10.1016/j.ecolmodel.2011.09.009

14. Indramayu District. 2013. Regent Instruction Number 3/2014 about the acceleration of technology innovation for rice by using jajar legowo system. The regional Government of Indramayu District.

15. Irawan, B. 2016. Konversi Lahan Sawah: Potensi Dampak, Pola Pemanfaatannya, Dan Faktor Determinan. In Forum Penelitian Agro Ekonomi, 23(1), $1,1-18$

16. Jiang, G.H., F.R. Zhang, X.B. Kong. 2019. Determining Conversion Direction Of The Rural Residential Land Consolidation In Beijing Mountainous Areas. Transactions of the CSAE; 25(2), 214-221.

17. Jpnn. 2017. This is The cultural Technology Innovation for Rain-fed Rice Fields (in Indonesian). [Online]. Available https://www.jpnn.com/kementan/news/inilah-inovasi-teknologi-budidaya-padidi-sawah-tadah-hujan

18. Kamilah, A. 2013. EconomicAnalysis on Agricultural Land Conversion: Study Case in North Bekasi Sub-District and Bantar Gebang (in Indonesian). Jurnal Agribisnis dan Pengembangan Wilayah; 5(1), 36-49.

19. Kamusoko, C., Aniya, M., Adi, B., \& Manjoro, M. 2009. Rural sustainability under threat in Zimbabwe-simulation of future land use/cover changes in the Bindura district based on the Markov-cellular automata model. Applied Geography;29(3), 435-447, doi.org/10.1016/j.apgeog.2008.10.002

20. The ministry of Domestics affair Gazette 2013. The Indramayu District Regulation about the Protection of Sustainable Crops Land. Lembaran Kementerian dalam Negeri Republik Indonesia 2013.

21. Lark, T.J., Mueller, R.M., Johnson, D.M., \& Gibbs, H.K. 2017. Measuring land-use and land-cover change using the US department of agriculture's cropland data layer: Cautions and recommendations. International Journal of Applied Earth Observation and Geoinformation; (62), 224-235. doi. org/10.1016/j.jag.2017.06.007

22. Luan, Y., Cui, X., \& Ferrat, M. 2013. Historical trends of food self-sufficiency in Africa. Food Security; 5(3), 393-405.

23. Ma, L., Li, M., Ma, X., Cheng, L., Du, P., \& Liu, Y. 2017. A review of supervised object-based landcover image classification. ISPRS Journal of Photogrammetry and Remote Sensing; 130, 277-293. Doi: 10.1016/j.isprs.2017.06.001

24. Ministry of Agriculture. Appendices 1: The MInitsry of Agriculture Decree/ The chairman of Food Security Council, No. 43 /Permentan/ OT.140/7/2010. 2014. The National Guidelines for the Food and Nutrition Awareness System. Ministry of Agriculture. Jakarta. 
25. Minsistry of Agriculture. 2015. Food Consumtion Statistics 2015. Ministry Of Agriculture. Jakarta. .

26. Mondal, M.S., Sharma, N., Garg, P.K., \& Kappas, M. 2016. Statistical independence test and validation of CA Markov land use land cover (LULC) prediction results. The Egyptian Journal of Remote Sensing and Space Science;19(2), 259-272.

27. Mulyani, A., Kuntjoro, D., Nursyamsi, D., \& Agus, F. 2016. Indonesian Rice fields Conversion AS The Threat to Food Security (in Indonesian). Jurnal Tanah dan Iklim Jurnal Tanah dan Iklim, (Indonesian Soil and Climate Journal); 40(2), 121-133, doi: http://dx.doi.org/10.2017/jti.v40i2.5708

28. Nahayo, A., Omondi, M.O., Zhang, X.H., Li, L.Q., Pan, G.X., \& Joseph, S. 2017. Factors influencing farmers' participation in crop intensification program in Rwanda. Journal of integrative agriculture; 16(6), 1406-1416. doi.org/10.1016/ S2095-3119(16)61555-1

29. Noviasari, S., Kusnandar, F., \& Budijanto., S. 2013. Development of White Corn-Based Rice Analogues (in Indonesian). Jurnal Teknologi dan Industri Pangan; 24(2), 194-200, doi: 10/6066/ jtip.2013.24.2.194.

30. Pasandaran, E. 2006. The Policy Alternative to Control Irrigated Rice Fields Conversion (in Indonesian). Jurnal Litbang Pertanian; 25(4),

31. Pikiran Rakyat. 1100.000 ha Annual Decreasing of Agricultural lands (in Indonesian). Cited from http://www.pikiran-rakyat.com/ jawa-barat/2016/06/13/100000-hektare-lahan-pertanian-menyusut-setiap-tahun-371703

32. Rahman, H.P. 2001. The Assessment of The Pattern of Food Consumption and Demand in The Eastern Part Of Indonesia (in Indonesian). Dissertation. Bogor Agricultural University. Bogor.

33. Render, B. 2006. Quantitative analysis for management. Pearson Education India.

34. Rohi I.R. 2008. Effective Communication Of Peasant Group Leaders in Applying Rice Farming Technology (in Indonesian). Thesis. Bogor Agricultural University. Bogor

35. Saputra, I.M. 2015. Analysis of Rice Self-Sufficiency in 26 Districts/Cities in West Java Province (in Indonesian). Thesis. Bogor Agricultural University. Bogor
36. Suradisastra, K. 2006. Institutions Revitalization to Accelerate The Agriculture Development in the Authonomy Era (in Indonesian). Analisis Kebijakan Pertanian; 4(4), 281-314

37. Suyastiri, N.M, Y.P. 2008. Food Consumption Diversification Based on Local Potency to Support The Individual Village Households in Semin Village, Gunung Kidul District (in Indonesian). Jurnal ekonom Pembangunan; 13(1), 51-60

38. Wang, H., Qiu, F., \& Ruan, X. 2016. Loss or gain: A spatial regression analysis of switching land conversions between agriculture and natural land. Agriculture, Ecosystems \& Environment; 221, 222-234. doi.org/10.1016/j.agee.2016.01.041Woodard

39. Widayati, W. 2015. The policy for sustainable agricultural land protection in Demak Regency (in Indonesian). Jurnal Ilmiah Ilmu Pemerintahan; 1(1): 5-11.

40. Woodard, J.D. 2016. Integrating high resolution soil data into federal crop insurance policy: Implications for policy and conservation. Environmental Science \& Policy, 66, 93-100. https://doi. org/10.1016/j.envsci.2016.08.011

41. Yami, M., \& Van Asten, P. 2017. Policy support for sustainable crop intensification in Eastern Africa. Journal of Rural Studies, 55, 216-226. https://doi. org/10.1016/j.jrurstud.2017.08.012

42. Yang, G.Q., Liu, Y.L., \& Wu, Z.F. 2007. Analysis and simulation of land-use temporal and spatial pattern based on CA-Markov model. Geomatics and Information Science of Wuhan University; 32(5), 414-418.

43. Zaini, Z. 2009. Accelerating The Rice Production By Using Innovation Technology of Specific Location in The Green Revolution Era (in Indonesian). Jurnal Pengembangan Inovasi Pertanian, 2(1), $35-47$

44. Xiyong, H., Bin, C., \& Xinfang, Y. 2004. Land use change in Hexi corridor based on CA-Markov methods [J]. Transactions of The Chinese Society of Agricultural Engineering;(5), 286-291.

45. Zare, Mohammad, Thomas Panagopoulos, Luis Loures. 2017. Simulating the impacts of future land use change on soil erosion in the Kasilian watershed, Iran. Land Use Policy; 67, 558-572. doi. org/10.1016/j.landusepol.2017.06.028 